\title{
A new serial Cretaceous planktic foraminifer (Family Heterohelicidae Cushman, 1927) from the Upper Maastrichtian of the equatorial Central Pacific
}

\author{
M. DAN GEORGESCU ${ }^{1} \&$ SIGAL ABRAMOVICH ${ }^{2}$ \\ ${ }^{1}$ Department of Geoscience, University of Calgary, 2500 University Drive Northwest, Calgary, Alberta T2N 1N4, Canada \\ (e-mail: dgeorge@ucalgary.ca) \\ ${ }^{2}$ Department of Geological and Environmental Sciences, Ben Gurion University of the Negev, PO Box 653, Beer Sheva 84105, Israel
}

\begin{abstract}
A new serial planktic foraminifer, Lipsonia lipsonae nov. gen., nov. sp., is reported from the Upper Maastrichtian sediments of the equatorial Central Pacific (Shatsky Rise). It presents raised sutures throughout, ornamentation consisting of coarse irregular structures on the early part of the test and smooth test surface in the adult stage. The absence of costate ornamentation suggests that the new taxon origins should probably be found in the contemporaneous non-costate species of the Laeviheterohelix glabrans - L. dentata group. Lipsonia lipsonae presents morphological similarities with the Santonian genus Sigalia. The costate test surface and sutures of the latter indicates that it evolved from a costate species. Accordingly, Lipsonia and Sigalia are the results of iterative evolution from two different heterohelicid groups. J. Micropalaeontol. 27(2): 117-123, November 2008.
\end{abstract}

KEYWORDS: planktic foraminifera, Upper Cretaceous, equatorial Central Pacific, taxonomy, Lipsonia lipsonae nov. gen, nov. $s p$

\section{INTRODUCTION}

Cretaceous planktic foraminifera with multiserial chamber growth in the adult stage have occurred since the Coniacian (lowermost Senonian). Weiss (1983) recognized two distinct stratigraphical intervals of occurrence of these taxa: ConiacianLower Campanian and Upper Campanian-Maastrichtian, respectively. This concept was accepted subsequently by Nederbragt $(1989,1991)$. All the Cretaceous representatives of the serial planktic foraminifera (Family Heterohelicidae) with multiserial chamber growth in the adult became extinct at the Cretaceous/Tertiary boundary (Montanaro Gallitelli, 1957; Brown, 1969; Martin, 1972; Weiss, 1983; Nederbragt, 1991; Premoli Silva \& Sliter, 1995).

The planktic foraminiferal taxa of the Late Cretaceous, which present chamber proliferation in the adult stage, can be subdivided informally into two categories, according to the nature of the intercameral sutures. The first category includes those tests with raised sutures and it includes a single genus: Sigalia Reiss, 1957 of the Santonian. The other category consists of all the other taxa with multiserial chamber growth in the adult stage: Ventilabrella Cushman, 1928 (Coniacian-Lower Campanian), Planoglobulina Cushman, 1927 (Upper CampanianMaastrichtian), Gublerina Kikoine, 1948 (Upper CampanianMaastrichtian), Racemiguembelina Montanaro Gallitelli, 1957 (Maastrichtian) and partly Pseudotextularia Rzehak, 1891, namely $P$. intermedia de Klasz, 1953 of the Maastrichtian. The development of the raised intercameral sutures between the successively added chambers, as initially considered by Reiss (1957) with the definition of Sigalia, was validated subsequently as a diagnostic feature at genus level by Loeblich \& Tappan (1987) and Nederbragt (1991).

A new planktic foraminifer taxon, which is formalized at genus level, is reported from the Upper Maastrichtian sediments of the central equatorial Central Pacific (Shatsky Rise). It presents raised sutures between the chambers, test surface without costae and well-developed proliferating stage with up to seven chamberlets in the last-formed chamber sets. Apparently, Lipsonia lipsonae is the result of an iterative evolution process, which resulted in the development of tests with relatively similar morphological features in distant lineages. Such a process was observed originally in the Tertiary planktic foraminifera by Steineck \& Fleisher (1978). Taxonomical applications of this concept in the case of the serial planktic foraminifera of the Upper Cretaceous were discussed recently by Georgescu (2007a, b).

\section{MATERIAL AND ITS PROVENANCE}

All the material analysed for this study comes from three wells drilled under the auspices of the Deep Sea Drilling Project (DSDP) and Ocean Drilling Program (ODP) - DSDP Sites 305, 463 and 577 and ODP Hole 1212B. All these sites lie in the equatorial Central Pacific (Shatsky Rise). A complete set of samples from ODP Hole 1212B and only spot samples from the other three were investigated.

Overall, 300 specimens of Lipsonia lipsonae nov. gen., nov. sp. were collected and studied, all of them from the Upper Maastrichtian sediments belonging to the Pseudoguembelina hariaensis Biozone. The state of preservation was mostly excellent, but it was also possible to identify levels in which the larger specimens were affected by dissolution to varying degrees.

The specimens of Lipsonia lipsonae were compared with other Cretaceous multiserial planktic foraminiferal species of the genera Sigalia, Planoglobulina and Gublerina, all presenting multiserial chamber growth in the plane of the early biserial stage. This material came from the following DSDP/ODP sites: DSDP Site 95 (Yucatan Outer Shelf), DSDP Hole 111A (Orphan Knoll, North Atlantic), DSDP Site 152 (Nicaragua Rise, Caribbean), DSDP Site 305 (Shatsky Rise, Pacific Ocean), DSDP Site 463 (Mid-Pacific Mountains), DSDP Site 356 (São Paolo Plateau, western South Atlantic), DSDP Site 357 (Rio Grande Rise, western South Atlantic), DSDP Site 384 (Grand 


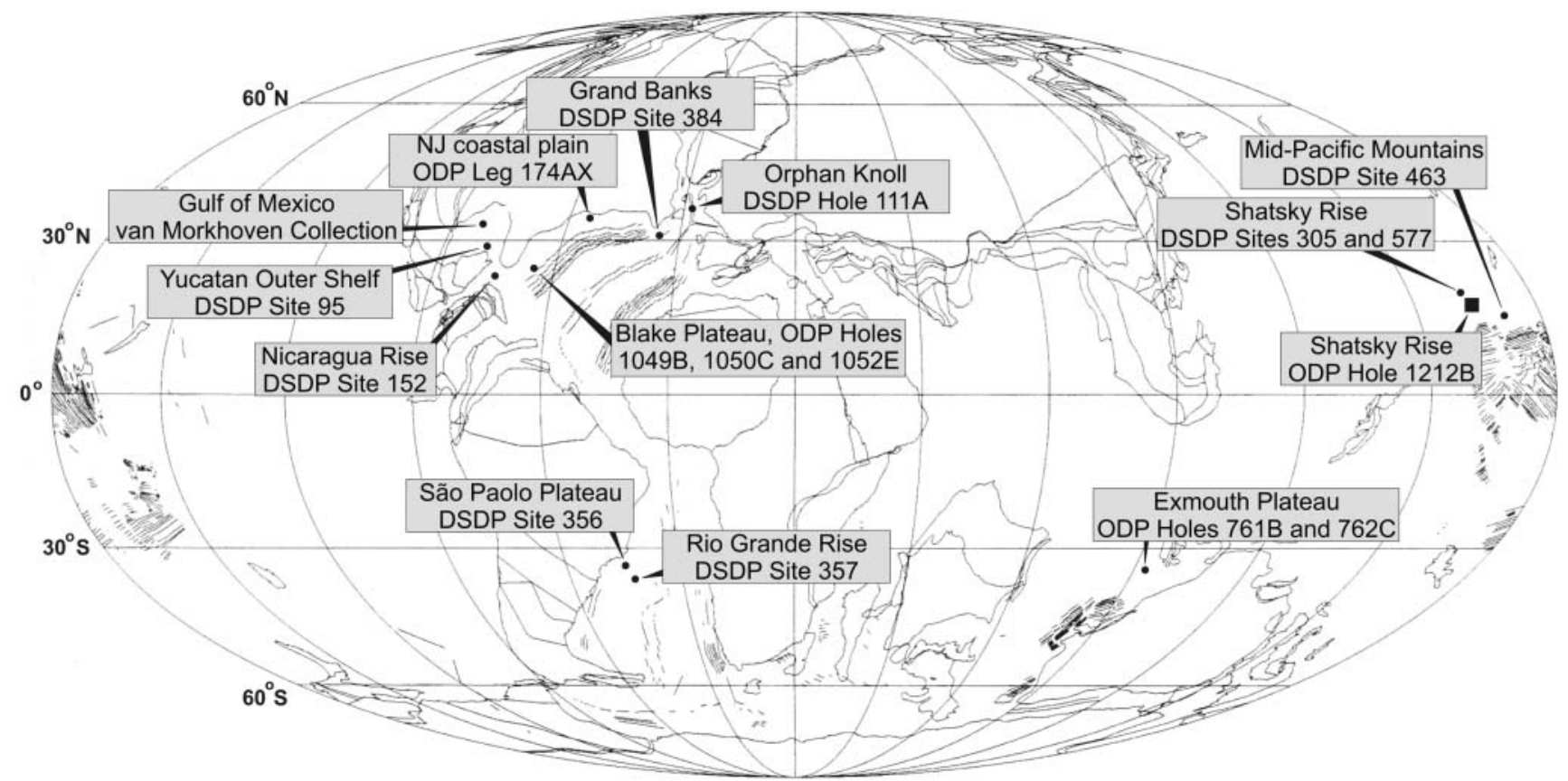

Fig. 1. Geographical position of the type locality for Lipsonia lipsonae nov. gen., nov. sp. (filled square, Shatsky Rise, equatorial Central Pacific, ODP Hole 1212B). Palaeogeographical reconstruction after Hay et al. (1999).

Banks, North Atlantic), ODP Leg 174AX (New Jersey coastal plain), ODP Holes 1049B, 1050C and 1052E (western North Atlantic, Blake Plateau), ODP Holes 761B, 762C (Exmouth Plateau, Indian Ocean) (Fig. 1). Additional comparison material came from the van Morkhoven Collection, deposited at the National Museum of Natural History (Smithsonian Institution, Washington, D.C.).

\section{TAXONOMY}

Suprageneric classification is after Loeblich \& Tappan (1987).

Order Foraminiferida Eichwald, 1830

Suborder Globigerinina Delage \& Hérouard, 1896

Superfamily Heterohelicacea Cushman, 1927

Family Heterohelicidae Cushman, 1927

Genus Lipsonia nov.

Type species. Lipsonia lipsonae nov. sp.

Derivation. Genus named in honour of Dr S. Lipson-Benitah (Geological Survey of Israel) for her outstanding contribution to knowledge of Cretaceous planktic foraminifera.

Diagnosis. Multiserial planktic foraminifer with raised sutures throughout and coarse irregular ornamentation of the earlier part of the test and smooth in the portion with the last-formed chamberlet sets.

Species included. The genus is so far monospecific.
Phylogenetic relationships. The origins of Lipsonia nov. gen. are unknown. The absence of the costate ornamentation suggests a possible ancestry among the non-ornamented Laeviheterohelix species, such as L. glabrans (Cushman, 1938) and L. dentata (Stenestad, 1968). However, these two species have compressed tests and, for this reason, cannot be considered among the potential direct ancestors of Lipsonia.

Description. Test is flabelliform in shape, with a very short biserial stage followed by a well-developed multiserial one consisting of up to ten chamberlet sets following the progressive chamber. Chambers are semicircular to subcircular, bordered by raised sutures throughout. The test has quasi-parallel sides in edge view and distinct thickening in the earlier part due to the addition of successive layers of calcite. Aperture is multiple in the adult stage, with circular to ovate transverse walls. Ornamentation consists of coarse and irregular structures on the earlier part of the test; the last-formed chambers are smooth. Test wall is calcareous, hyaline, with variable porosity, macroperforate with vuggy pores in the earlier part and microperforate to finely perforate in the adult.

Stratigraphical range. Upper Maastrichtian, namely the upper part of the Pseudoguembelina hariaensis Biozone as defined by Robaszynski \& Caron (1995).

Geographical distribution. Equatorial Central Pacific (Shatsky Rise), western United States (California) and northwestern Mexico (Baja California). 


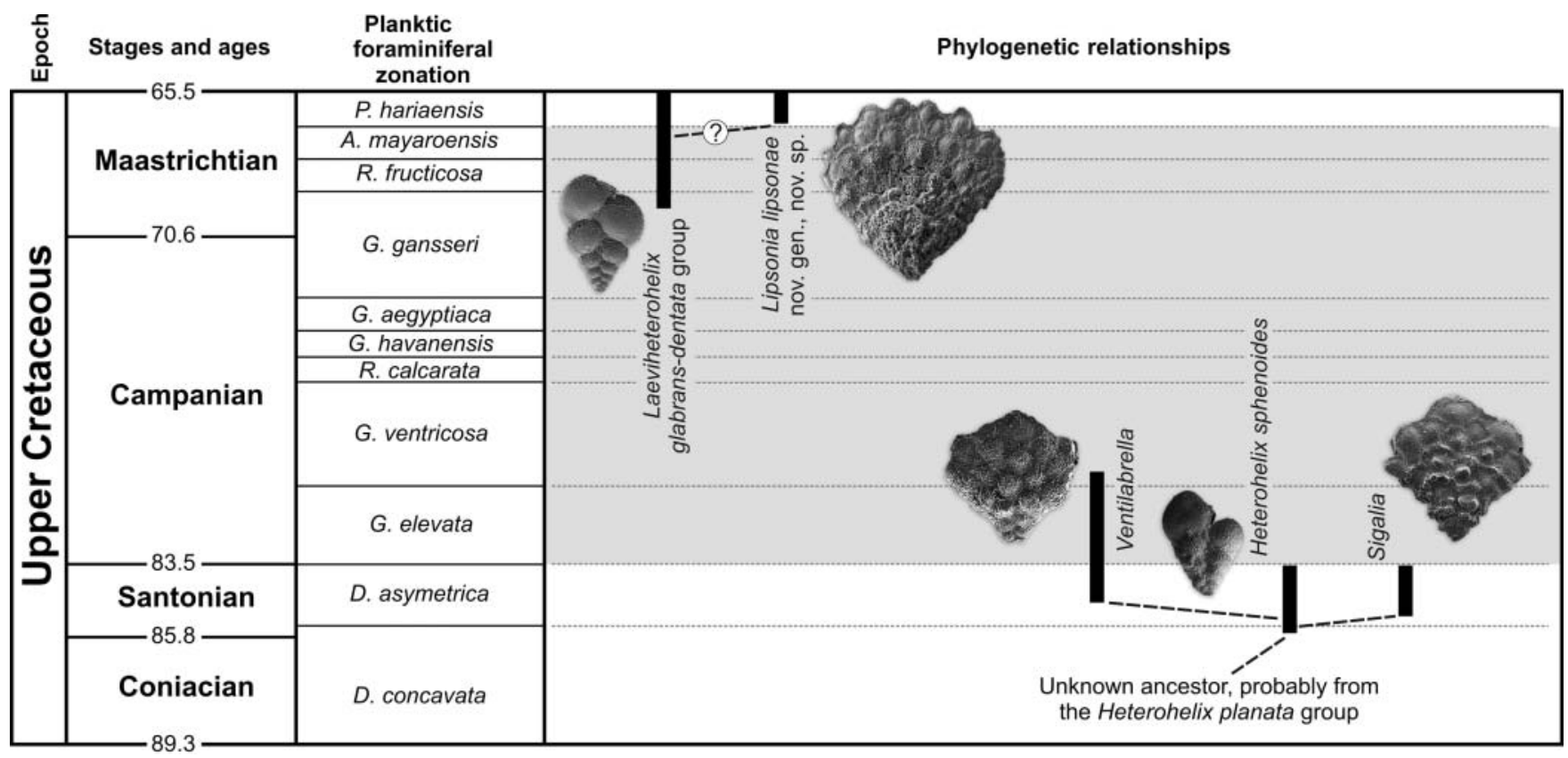

Fig. 2. The different phylogenetic origins of the two Cretaceous serial planktic foraminiferal genera with multiserial chamber growth in the adult stage and raised sutures throughout, Sigalia (Santonian) and Lipsonia (Upper Maastrichtian). The light grey shading indicates the stratigraphic interval in which such tests are not recorded, supporting the different phylogenetic origins of the two genera and, therefore, the taxonomic separation at genus level. Ages after Gradstein et al. (2004). Planktic foraminiferal zonation after Robaszynski \& Caron (1995).

Remarks. Only two Cretaceous serial planktic foraminiferal genera present raised sutures: Sigalia and Lipsonia nov. Although the two are nearly homeomorphs, they differ in a number of features, such as: (i) the multiserial stage is better developed in Lipsonia (up to ten chamberlet sets) when compared to Sigalia (maximum six chamberlet sets); (ii) test ornamentation in Lipsonia is completely devoid of costae, whereas fine costae are present in all species of Sigalia; (iii) the thickened early part of the test differs sharply in the two genera: it is completely irregular in Lipsonia and with a radial pattern in Sigalia. The finely costate surface and raised sutures of Sigalia suggest that the origin of this genus should be most likely in the costate contemporaneous Heterohelix sphenoides Masters, 1976, as suggested by Nederbragt (1991). The complete absence of costate ornamentation rules out a costate ancestor for Lipsonia (Fig. 2). The two genera are separated by a significant time gap, which encompasses the Campanian-Lower Maastrichtian stratigraphical interval (approximately $17 \mathrm{Ma}$ ). This gap is calculated from the last occurrence of Sigalia (Santonian, top of the Dicarinella asymetrica Biozone) to the first evolutionary occurrence of Lipsonia lipsonae (Upper Maastrichtian, Pseudoguembelina hariaensis Biozone). Accordingly, it can be inferred that the two genera apparently evolved as the result of iterative evolution. The raised sutures are distinctive for Lipsonia when compared with Ventilabrella. There are significant differences between the smooth Lipsonia and strongly ornamented Planoglobulina, the latter presenting either strong longitudinal costae or small-sized structures arranged following a vermicular pattern.
Lipsonia lipsonae nov. sp.

(Pl. 1, figs 1-4; Pl. 2, figs 1-2; Pl. 3, figs 1-6)

1968 Planoglobulina ornatissima (Cushman \& Church); Sliter: 97, pl. 14, fig. 10 .

Derivation. As for the genus.

Holotype. Specimen USNM 534381 (National Museum of Natural History, Smithsonian Institution, Washington, D.C.).

Paratypes. Five specimens, Slide USNM 534382.

Phylogenetic relationships. As for the genus.

Type locality. ODP Hole 1212B; geographical coordinates: $32^{\circ} 26.9070 \mathrm{~N}$ and $157^{\circ} 42.7002 \mathrm{E}$.

Type level. Upper Maastrichtian (Pseudoguembelina hariaensis Biozone) nannofossil ooze, sample 198-1212B-13-3, 148-150 cm.

Description. Test is flabelliform, with nearly straight sides and with an early biserial stage followed by a multiserial adult one. The earlier stage can be observed with difficulty due to the addition of successive layers of calcite; it is followed by the progressive chamber, and then by a multiserial stage consisting of 8 to 10 chamberlet sets. The multiserial stage consists of 45 to 61 chambers. The test presents quasi-parallel faces in edge view only in the adult portion of the test; it is lens shaped in the early 


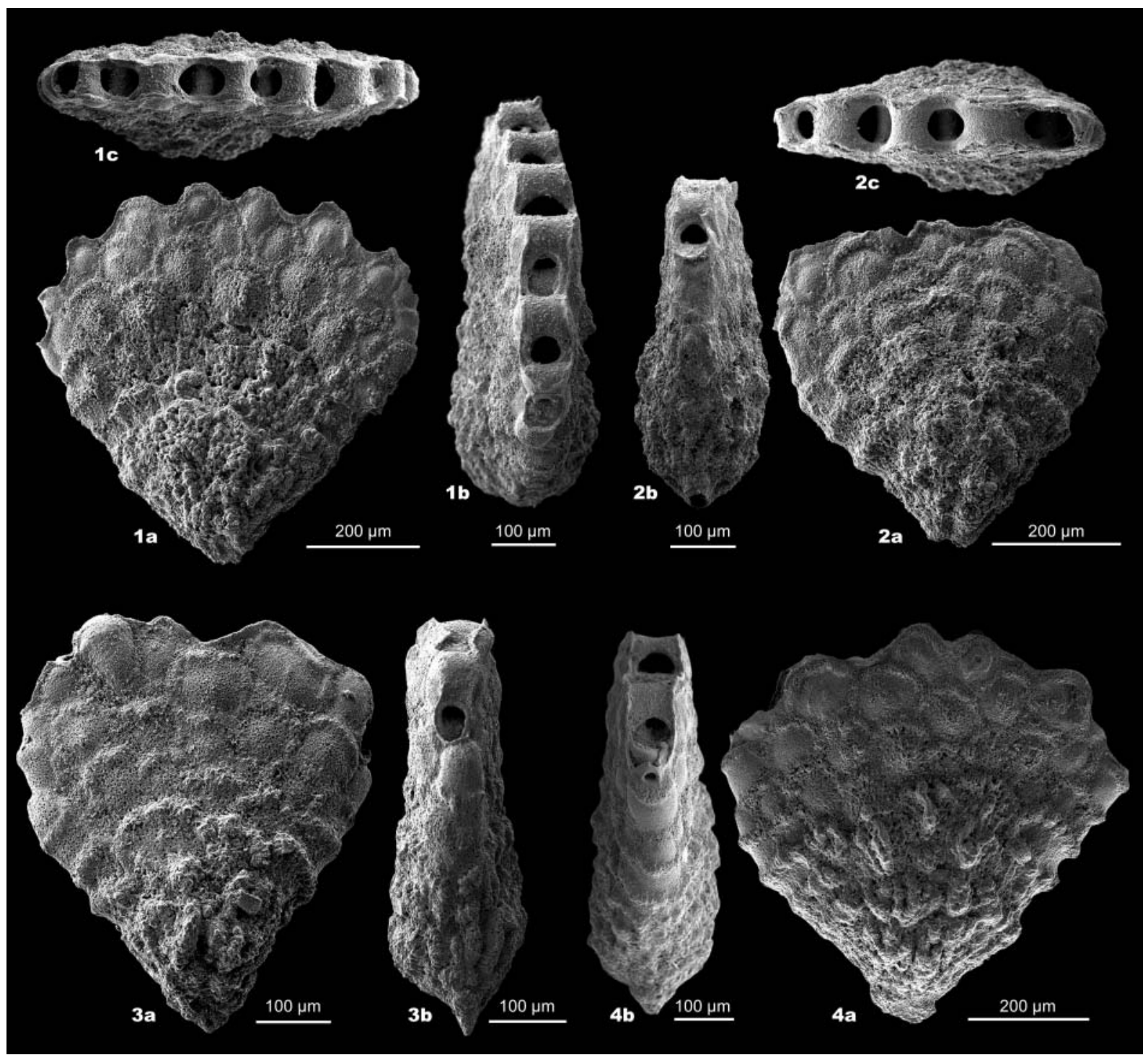

Explanation of Plate 1.

Lipsonia lipsonae nov. gen., nov. sp. - type specimens from the Upper Maastrichtian (Pseudoguembelina hariaensis Biozone) of the Shatsky Rise, ODP Hole 1212B. fig. 1. holotype (198-1212B-13-3, 148-150 cm). fig. 2. paratype (198-1212B-13-3, 148-150 cm). fig. 3. topotype (198-1212B-13-1, 20-21 cm). fig. 4. topotype (198-1212B-13-1, 40-42 cm).

part due to the successive addition of calcite layers during ontogenetic development. The earlier part of the test can present peripheral strong and blunt costae, conferring a pseudo-keeled aspect to the test. Intercameral sutures are curved and raised, transverse to the periphery. The aperture is multiple in the adult stage, and presents thin, circular to ovate transverse walls. The early portion of the test is ornamented with coarse and irregular structures; the adult stage is smooth. Test wall is calcareous, hyaline and perforate. Pores vary in size and shape; they are circular to subcircular in shape and with diameters of $0.8-1.7 \mu \mathrm{m}$ in the adult part of the test; those of the earlier parts are vuggy, irregular in shape due to the development of coarse ornamentation and with maximum dimensions in the rage of 3.6 to $8.1 \mu \mathrm{m}$.

Dimensions. Holotype: length $(\mathrm{L})=0.683 \mathrm{~mm}$; width $(\mathrm{W})=0.685 \mathrm{~mm} ; \quad \mathrm{W} / \mathrm{L}=1.003 ; \quad$ thickness $\quad(\mathrm{T})=0.238 \mathrm{~mm}$;
$\mathrm{T} / \mathrm{L}=0.348$. Based on the average measurements of 16 specimens (holotype included): $\mathrm{L}=0.528-0.683 \mathrm{~mm} ; \mathrm{W}=0 . \quad 486-0.683$; $\mathrm{W} / \mathrm{L}=0.856-1.126 ; \mathrm{T}=0.188-0.238 ; \mathrm{T} / \mathrm{L}=0.307-0.364$.

Stratigraphical range. Upper Maastrichtian (upper part of the Pseudoguembelina hariaensis Biozone).

Geographical distribution. Equatorial Central Pacific (Shatsky Rise) and western United States (California) and northwestern Mexico (Baja California).

Remarks. Lipsonia lipsonae nov. sp. differs from Planoglobulina multicamerata (de Klasz, 1953) in (i) having raised sutures between all the chambers of the test, (ii) lacking costate or reticulate ornamentation and (iii) presenting test wall with pores of variable size and shape, by contrast to the latter species in 


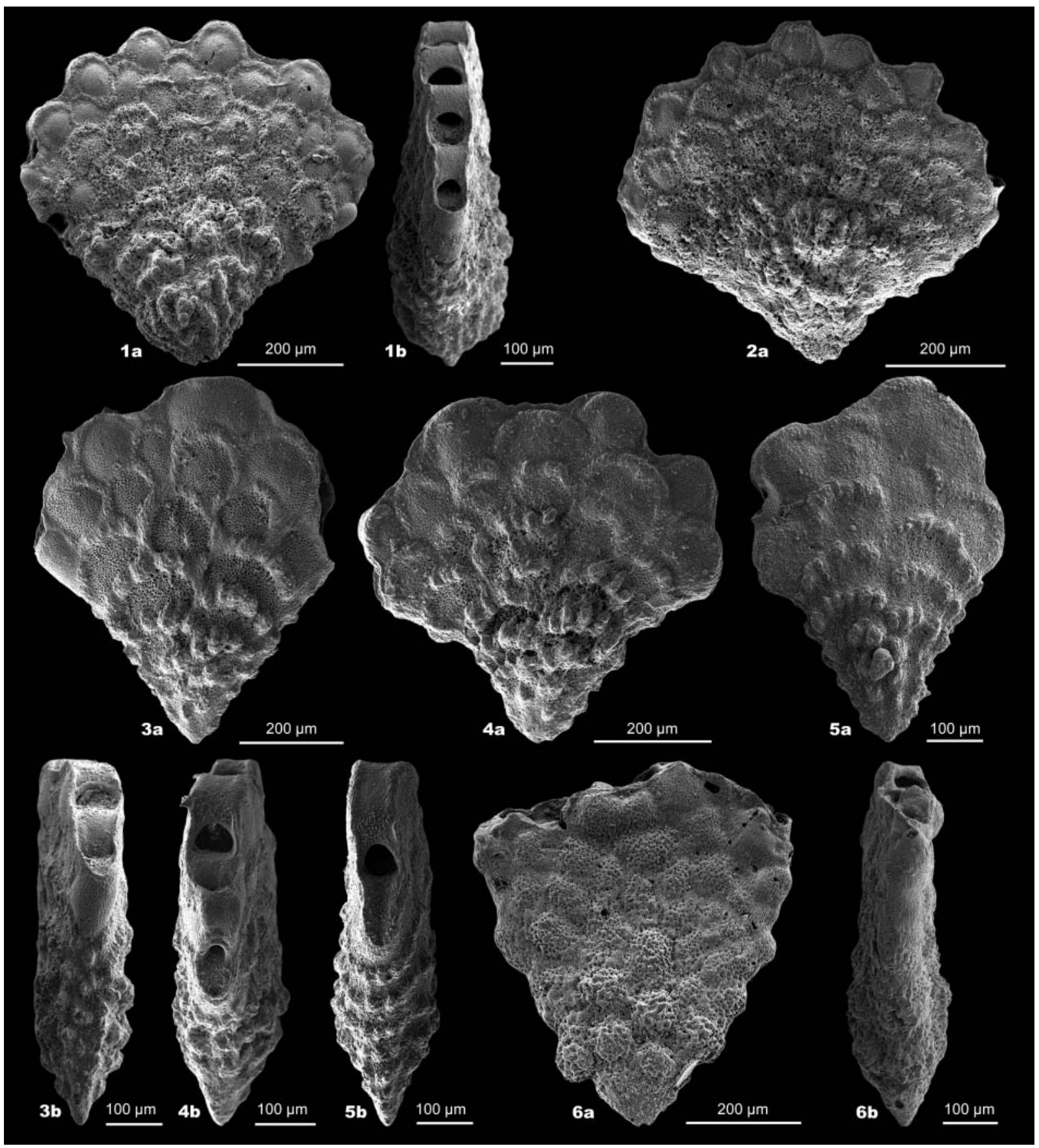

Explanation of Plate 2.

figs 1-2. Lipsonia lipsonae nov. gen., nov. sp., topotypes (198-1212B-13-1, 40-42 cm). figs 3-5. Sigalia decoratissima (de Klasz, 1953), hypotypes from Upper Santonian sediments (Dicarinella asymetrica Biozone) from the Gulf of Mexico (van Morkhoven Collection, NMNH, Washington, D.C.). fig. 6. Planoglobulina multicamerata (de Klasz, 1953), hypotype from Upper Maastrichtian (Abathomphalus mayaroensis Biozone) sediments of the northern Atlantic (Orphan Knoll, DSDP Hole 111A), sample 12-111A-11-2, 123-137 cm.

which the pores are circular and small-sized (diameters ranging between 0.7 and $1.2 \mu \mathrm{m}$, as shown in Plate 2, fig. 6). Sigalia decoratissima (de Klasz, 1953) is nearly a homeomorph of Lipsonia lipsonae but, in general, it presents a finely costate chamber surface or this pattern can be observed at least on the raised sutures. The former also presents strong thickenings on the earlier portion of the test due to the addition of successive layers of calcite during the ontogenetic development. However, they maintain a quasi-radial pattern ( $\mathrm{Pl}$. 2, figs 3-5), which is not present in L. lipsonae. The multiserial stages of the two taxa show significant differences, consisting of smaller chamberlets, which are arranged in up to ten sets in L. lipsonae and of larger chambers distributed in up to six multiserial chamberlet sets in S. decoratissima. 


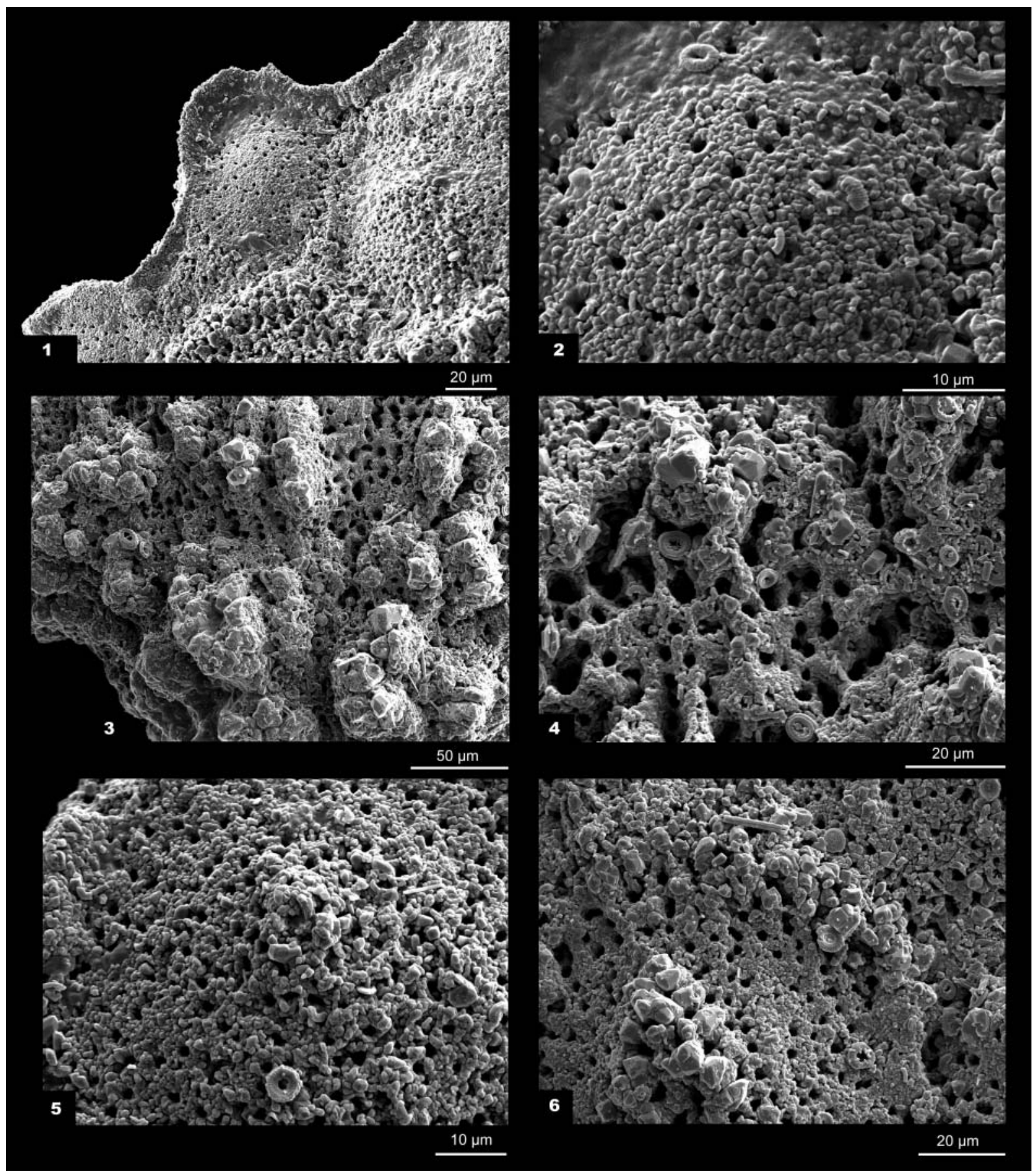

Explanation of Plate 3.

Detail scanning electron microscope photographs revealing the test ultrastructure of Lipsonia lipsonae nov. gen., nov. sp. figs 1-2. Holotype (198-1212B-13-3, 148-150 cm). figs 3-6. Another topotype, different from those figured in the previous plates (198-1212B-13-1, 20-21 cm).

The regular growth pattern in the adult stage separates $L$. lipsonae from Ventilabrella (?) ornatissima (Cushman \& Church, 1929); the latter is a species with irregular addition of chambers in the adult stage (Cushman \& Church, 1929, p. 512, pl. 39, figs 12-15). Accordingly, the report by Sliter (1968) is considered as representing the newly proposed taxon, $L$. lipsonae.

\section{DISCUSSION AND CONCLUSIONS}

The detailed study of the serial planktic foraminifera of the Upper Maastrichtian sediments from ODP Hole 1212B revealed the existence of a new taxon of this group, which is formalized as Lipsonia lipsonae nov. gen., nov. sp. This genus is characterized by lack of costate ornamentation, which is a characteristic among the Cretaceous serial planktic foraminifera with chamber 
proliferation in the adult stage. The test surface in L. lipsonae is smooth in the adult portion of the test and ornamented with coarse and irregularly developed structures in the early part, as a result of successive addition of calcite layers during the ontogenetic development. Ornamentation thickenings are also present in Sigalia decoratissima of the Santonian but, in contrast to $L$. lipsonae, they present a radial pattern as a result of the costate ornamentation. Another morphological characteristic of $L$. lipsonae among the multiserial planktics of the Campanian-Maastrichtian is the development of raised intercameral sutures. Similar structures are known only in the finely costate Santonian genus Sigalia. The detailed scanning electron microscope-based study revealed that Sigalia's raised sutures present costate ultrastructure, which contrasts with the nonornamented ones of Lipsonia. Lipsonia lipsonae presents one of the highest rates of chamber proliferation (up to ten chamberlet sets) among the Cretaceous serial planktic taxa, resembling Planoglobulina multicamerata of the Maastrichtian from this perspective. Moreover, the two taxa sharply differ due to the presence of depressed sutures and reticulate test ornamentation in the latter.

Lipsonia lipsonae nov. gen., nov. sp. appears to have evolved from the non-costate Laeviheterohelix glabrans-L. dentata group of species. This phylogenetic relationship needs further documentation as no specimens are known with intermediate morphology between them.

\section{ACKNOWLEDGEMENTS}

The authors thank Dr H. W. Bailey for critically reviewing the manuscript and Dr F. J. Gregory (Editor) for additional careful review. The professional and enthusiastic support during the SEM operations by Mr S. Whitaker (National Museum of Natural History, Smithsonian Institution, Washington, D.C.) is greatly appreciated. Thanks also go to the IODP headquarters for allowing the resampling of the Maastrichtian section of ODP Hole 1212B. The pre-submittal critical review of the manuscript and English language improvements suggested by Dr L. V. Hills (University of Calgary) are greatly appreciated.

\section{Manuscript received 30 October 2007 Manuscript accepted 20 July 2008}

\section{REFERENCES}

Brown, N.K. Jr 1969. Heterohelicidae Cushman, 1927, amended, a Cretaceous planktonic foraminiferal family. Proceedings of the First International Conference on Planktonic Microfossils, Geneva 1967, 2: 21-67.

Cushman, J.A. 1927. Some new genera of the foraminifera. Contributions from the Cushman Foundation for Foraminiferal Research, 3: 71-81.

Cushman, J.A. 1928. Additional genera of the foraminifera. Contributions from the Cushman Foundation for Foraminiferal Research, 4: 1-8.

Cushman, J.A. 1938. Cretaceous species of Gümbelina and related genera. Contributions from the Cushman Laboratory for Foraminiferal Research, 14: 2-28.
Cushman, J.A. \& Church, C.C. 1929. Some Upper Cretaceous foraminifera from near Coalinga, California. Proceedings of the California Academy of Sciences, 16: 497-530.

Georgescu, M.D. 2007a. A new planktonic foraminiferal genus (Family Heterohelicidae Cushman, 1927 ) of the Upper Cretaceous (Turonian). Micropaleontology, 53: 212-220.

Georgescu, M.D. 2007b. Taxonomic re-evaluation of the late Cretaceous serial planktonic foraminifer Gümbelina punctulata Cushman, 1938 and related species. Revista Española de Micropaleontologia, 39: 155-167.

Gradstein, F.M., Ogg, J.G. \& Smith, A.G. 2004. A Geologic Time Scale 2004. Cambridge University Press, Cambridge, 589pp.

Hay, W.H., DeConto, R.M., Wold, C.N., Wilson, K.M., Voigt, S., Schulz, M., Wold, A.R., Dullo, W.C., Ronov, A.B., Balukhovsky, A.N. \& Söding, E. 1999. Alternative global Cretaceous paleogeography. In: Barrera, E. \& Johnson, C.C. (Eds), Evolution of the Cretaceous Ocean-Climate System. Geological Society of America, Special Publication, 332: 1-47.

Kikoïne, J. 1948. Les Heterohelicidae du Crétacé supérieur pyrénéen. Bulletin de la Société Géologique de France, Série 5e 18 (1): 15-35.

Klasz, I. de 1953. Einige neue oder wenig bekannte Foraminiferen aus der helvetischen Oberkreide der bayerischer Alpen, südlich Traunstein (Oberbayern). Geologica Bavarica, 17: 245-251.

Loeblich, A.R. Jr \& Tappan, H. 1987. Foraminiferal genera and their classification. Van Nostrand Reinhold Company, New York, 970pp.

Martin, S.E. 1972. Reexamination of the Upper Cretaceous planktonic foraminiferal genera Planoglobulina Cushman and Ventilabrella Cushman. Journal of Foraminiferal Research, 2: 73-92.

Masters, B.A. 1976. Planktonic foraminifera from the Upper Cretaceous Selma Group, Alabama. Journal of Paleontology, 50: 318-330.

Montanaro Gallitelli, E. 1957. A Revision of the Foraminiferal Family Heterohelicidae. In: Loeblich, A.R. Jr (Ed.), Studies in Foraminifera. United States National Museum Bulletin, 215: 133-154.

Nederbragt, A.J. 1989. Chamber proliferation in the Cretaceous planktonic foraminifera Heterohelicidae. Journal of Foraminiferal Research, 19: $105-114$.

Nederbragt, A.J. 1991. Late Cretaceous biostratigraphy and development of Heterohelicidae (Planktic foraminifera). Micropaleontology, 37: 329-372.

Premoli Silva, I. \& Sliter, V.W. 1995. Cretaceous planktonic foraminiferal biostratigraphy and evolutionary trends from the Bottaccione section, Gubbio, Italy. Palaeontographia Italica, 92: 1-89.

Reiss, Z. 1957. Notes on foraminifera from Israel; 3 - Sigalia, a new genus of foraminifera. Bulletin of the Research Council of Israel, 6: 239-244.

Robaszynski, F. \& Caron, M. 1995. Foraminifères planctoniques du Crétacé: commentaire de la zonation Europe-Mèditerranée. Bulletin de la Société Géologique de France, 6: 681-692.

Rzehak, A. 1891. Die Foraminiferen-Fauna der alttertiären Ablagerungen von Brunderndorf in Niederösterreich, mit Berücksichtigung des angeblichen Kreidevorkommens von Leitzersdorf. Annalen des naturhistorischen Hofmuseums, Wien, 6: 1-12.

Sliter, W.V. 1968. Upper Cretaceous Foraminifera from Southern California and northwestern Baja California, Mexico. The University of Kansas Paleontological Contributions, 49 (7): 1-141.

Steineck, P.L. \& Fleisher, R.L. 1978. Towards the classical evolutionary reclassification of Cenozoic Globigerinacea (Foraminiferida). Journal of Paleontology, 52: 618-635.

Stenestad, E. 1968. Three new species of Heterohelix Ehrenberg from the upper Senonian of Denmark. Meddelelser fra Dansk Geologisk Forening, 18: 64-70.

Weiss, W. 1983. Heterohelicidae (seriale planktonische Foraminiferen) der tethyalen Oberkreide (Santon bis Maastricht). Geologisches Jahrbuch, A72: 1-96. 